\title{
Kršćanin ne može biti antisemit
}

\author{
Doprinos kršćansko-židovskomu dijalogu katoličke novinarke \\ Smiljane Rendić \\ Silvana Burilović Crnov*
}

\begin{abstract}
Sažetak
Rad istražuje doprinos prve hrvatske katoličke novinarke Smiljane Rendić kršćansko-židovskomu dijalogu. Propituje njezinu misao o odnosu Staroga i Novoga zavjeta, o odnosu Isusa Krista prema Zakonu. Analizira uzroke kršćanskoga antisemitizma i neodrživost teze o kolektivnoj odgovornosti Židova za bogoubojstvo. Kontekstualizira njezino tumačenje židovske povijesti i jezika te propituje održivost tvrdnje da je Crkva o antisemitizmu prekasno progovorila. Autorica se služi hermeneutskom metodom iščitavanja tekstova u njihovu kontekstu.
\end{abstract}

Ključne riječi: Smiljana Rendić; Židovi; kršćansko-židovski dijalog; antisemitizam; bogoubojstvo; kolektivna odgovornost; Nostra aetate; judaiziranje kršćanstva

\section{Uvod}

Drugi vatikanski koncil nadvladao je dugostoljetnu središnju teološku tradiciju Crkve koja je problem religija uglavnom sužavala na pitanje o mogućnosti individualnoga spasenja nekršćana. Koncil u mnogo čemu radikalno mijenja taj tradicionalni način mišljenja o religijama te potiče međureligijski dijalog kao jedini mogući način ophođenja kršćana s pripadnicima drugih religijskih tradicija, među njima i sa Židovima. Teološki ga temelji poglavito na ideji o zajedničkom izvorištu i cilju cjelokupne ljudske povijesti.

U ovih je više od pola stoljeća Crkva nastavila poticati taj dijalog, koji je doveo do boljega međusobnoga poznavanja i poštovanja. Činila je to s različitih razina, od svojih poglavara, putem crkvenih medija do istaknutih pojedinaca. Međutim, brojni su tekstovi — u hrvatskoj teološkoj i novinarskoj literaturi — još uvijek neistraženi, a mogu dati važan doprinos kršćansko-židovskomu dijalogu. Takvi su i tekstovi hrvatske katoličke novinarke Smiljane Rendić, koji se čine aktualnim i

* Dr. sc. Silvana Burilović Crnov, Voditeljica Informativnoga odjela Tiskovnoga ureda Splitskomakarske nadbiskupije. Adresa: Poljana kneza Trpimira 7, 21000 Split, Hrvatska. ORCID iD: https://orcid.org/0000-0002-1723-3404. E-adresa: silvana.burilovic@gmail.com 
važnim osobito danas kada smo svjedoci pojave jačanja antisemitizma u zapadnoj Europi, na što se tuže suvremeni Židovi. ${ }^{1}$

Smiljana Rendić (1926.-1994.) hrvatska je katolička novinarka, književnica, vatikanistica, prevoditeljica, polemičarka, judaistkinja i dugogodišnja suradnica Glasa Koncila. Jedina je dobitnica Zlatnoga pera Glasa Koncila. Autorica je nekoliko knjiga, stotine objavljenih članaka, a sačuvana je njezina obilna korespondencija s (nad)biskupima, urednicima tiskovina, profesorima teologije, novinarskim kolegama te ostalim crkvenim i svjetovnim osobama. Rendić se je koristila različitim pseudonimima, među kojima su najpoznatiji Berith i Vjera Marini, a tekstove je potpisivala i inicijalima, kraticama te punim imenom i prezimenom.

Slušajući Radio Vatikan na stranim jezicima i čitajući inozemni tisak, Rendić je s posebnom pozornošću pratila što se je na Koncilu govorilo o Židovima. Kritički je pratila razvoj situacije odnosa kršćana prema Židovima i nakon Koncila te je o tom pisala u crkvenim (Bakarska zvona, Glasnik sv. Antuna Padovanskoga, Glas Koncila i Marija) i svjetovnim tiskovinama (Kolo, Kritika i Marulić) te u osobnim pismima, koja nisu samo osobna, nego su i odraz njezina originalnoga promišljanja. Naime, iz pisama doznajemo da joj brojni tekstovi nisu objavljeni iz različitih razloga, od preopširnosti do toga što se nisu uklapali u uredničku politiku. ${ }^{2}$

U ovom radu, na temelju objavljenih tekstova Smiljane Rendić i njezinih pisama koji su važni za ovu tematiku, kontekstualizirano je njezino tumačenje židovske kulture, jezika i običaja, istražena je misao o Židovima, koje je smatrala jedinstvenim narodom, te se ispituje je li u njezinu pisanju riječ o judaiziranju kršćanstva ili o koncilskoj misli o povezanosti Staroga i Novoga zavjeta. Analizirane su njezine tvrdnje o uzrocima kršćanskoga antisemitizma i o neodrživosti teze o kolektivnoj odgovornosti Židova za bogoubojstvo temeljene na misli židovskoga povjesničara Julesa Isaaca. Propituje se održivost tvrdnje da je Crkva o antisemitizmu prekasno progovorila. Članak završavamo zaključnim mislima o važnom doprinosu hrvatske katoličke novinarke kršćansko-židovskomu dijalogu.

\section{O židovskoj kulturi, jeziku i običajima}

Smiljana Rendić slovila je kao jedna od boljih poznavatelja hebraistike u 20. stoljeću u Hrvatskoj te su se na njezinu misao o toj problematici referirali brojni znanstvenici (Čutura, 2012, 37-39). Rendić je smatrala izabrani narod Biblije simbolom čovječanstva, odnosno Izrael je na poseban način i simbol Kristove Crkve (Rendić, 1965a). Smatrala ga je jedinstvenim i po tom što je jedini dao Boga, Isusa Krista, proroke, apostole, Mariju, prvu Crkvu i Bibliju, što je jedini

1 Upućujemo na istraživanja o diskriminaciji i zločinima iz mržnje protiv Židova u EU koje je 2018. provela Agencija Europske unije za temeljna prava (FRA, 2018). Židovi zbog jačanja antisemitizma napuštaju Europu (Riegert, 2021).

2 Autorica ovoga članka jedina je do sada znanstveno istraživala život i djelo te katoličke novinarke (Burilović Crnov, 2019), čija je pisma prikupila iz različitih arhiva i privatnih zbirki osoba kojima je Rendić slala svoja pisma te iz njezine ostavštine u kojoj se nalazi sva njezina korespondencija a koja je po zadnjim saznanjima u fazi sređivanja i arhiviranja. 
bio »aušvicovan u šest milijuna i devedeset i tri tisuće svojih sinova i kćeri, od kojih je bilo milijun i osam stotina tisuća djece ispod četrnaest godina «. ${ }^{3}$ Ističe da se nijednomu drugomu narodu nije dogodila »stravična transpozicija kršćanske poganske zavisti«, koja je masakrirala Židove kao »kristoubojice«, a zapravo im nije mogla oprostiti što su »kristodavaoci «. ${ }^{4}$ Rendić je znala i hrvatske katoličke teologe nazvati antisemitima ako su Židove smatrali narodom poput svakoga drugoga naroda. Svoditi Izrael na »narod kao svaki drugi« smatrala je istim kao i moderno teološko svođenje Krista na »Verbum bez subjekta i objekta «. Smatrala je da se je onodobno u nas moglo javno biti kripto antisemit i otvoreno anticionist, ali ne i filosemit i filocionist. Odgovor na pitanje zašto je Bog izabrao baš Židove pronalazi u jednom midrašu te piše da je Izrael izabran »jer je bio jedini narod kadar prihvatiti Zakon Božji u čistom povjerenju, kadar odlučiti da će ga razumjeti tek vršeći ga «. ${ }^{5}$ Rabin Jacob Neusner o tom kaže da »živjeti prema zakonima koje je Bog odredio« za njihovo posvećenje njima znači biti vječni Izrael — kraljevstvo svećenika i svetoga naroda (Neusner, 2010, 208-209). ${ }^{6}$

Smiljana Rendić poznavala je veoma dobro židovsku povijest i tradiciju, jezik i kulturu. Posjedovala je zavidnu biblioteku s literaturom o judaizmu, primjerice knjige iz judaistike koje nitko nije imao u onodobnoj zemlji, pa ni knjižnica Saveza jevrejskih opština, ni fra Bonaventura Duda (1924.-2017.), veliki hrvatski bibličar koji je — po riječima Smiljane Rendić — bio oduševljen njezinom bibliotekom o judaizmu. ${ }^{7}$ Veliko stečeno znanje davalo joj je sigurnost da suvereno može sudjelovati u raspravama o judaizmu. Rasprava je u židovstvu jedan oblik službe Božje kao i molitva te predstavlja glavno sredstvo religioznoga dijaloga. S Bogom su tako raspravljali utemeljitelj vječnoga Izraela Abraham, Mojsije, Jeremija, Job i dr. Taj je čin rasprave u kontekstu Tore i »dar intelekta na žrtveniku Tore « (Neusner, 2010, 48). Iz toga možemo bolje razumjeti njezinu potrebu ulaženja u raspravu, kako unutarcrkvenu (Rendić, 1971b; Rendić, 2004) tako is onima izvan Crkve.

Oko imena Židov ušla je u polemiku s publicistom i izdavačem Slavkom Goldsteinom (1928.-2017.), koji je tražio da se u hrvatskom jeziku ime Židovi, kao kompromitirano Jasenovcem, zamijeni istočnim Jevreji. Rendić je smatrala da je srpskomu književnomu jeziku bilo jednostavno preuzeti naziv Jevrej iz ruskoga, ali ne i hrvatskomu jeziku. Tumačeći glasovne zakone i tomu slično zaključuje da su se u Hrvatskoj oni uvijek zvali Židovi i da je Židov jedini hrvatski ekvivalent

3 Osobni arhiv Silvane Burilović Crnov. Faksimilne kopije korespondencije Smiljane Rendić. Pismo Smiljane Rendić Tomislavu Šagi-Buniću od 22. travnja 1968. godine, str. 2.

4 Osobni arhiv Silvane Burilović Crnov. Faksimilne kopije korespondencije Smiljane Rendić. Pismo Smiljane Rendić Tomislavu Šagi-Buniću od 22. travnja 1968. godine, str. 2.

5 Osobni arhiv Silvane Burilović Crnov. Faksimilne kopije korespondencije Smiljane Rendić. Pismo Smiljane Rendić Tomislavu Šagi-Buniću od 9. travnja 1979. godine, str. 4.

6 Papa Benedikt XVI. Neusnerovu knjigu Rabin razgovara s Isusom nazivao je najvažnijom onodobnom knjigom za kršćansko-židovski dijalog te ju je više puta u svojim djelima citirao.

7 Osobni arhiv Silvane Burilović Crnov. Faksimilne kopije korespondencije Smiljane Rendić. Pismo Smiljane Rendić Iliji Martinoviću od 10. kolovoza 1982. godine, str. 6. 
talijanskomu nazivu Ebreo (Rendić, 1970a). ${ }^{8}$ Dodaje da je stari talijanski prezirni naziv Giudeo imao svoj stari hrvatski ekvivalent, obojen istim teološkim i socijalnim antisemitizmom: ̌̌udija ili Čifut.

Rendić piše o cionizmu, modernom pokretu židovskoga nacionalnoga osvješćivanja na utuk asimilaciji, koji je od svih južnoslavenski zemalja najprije niknuo u Hrvatskoj. Prvi cionisti u Hrvatskoj nazivali su sebe Židovima. Spominje prve cionističke listove u južnoslavenskim zemljama: Židov, koji je izlazio u Zagrebu, i Židovska svijest, koji je izlazio u Sarajevu. Cionisti i asimilanti u Bosni u prvom desetljeću stare Jugoslavije razlikovali su se i po tom što su prvi zvali sebe Židovima, a drugi Jevrejima. Tako su u Sarajevu izlazili asimilantski listovi Jevrejska tribuna i Jevrejski život (Rendić, 1970a, 407).

Rendić se protivila govoru da je naziv Izraelit eufemistička zamjena za nazive Ebreo, Jew, Jude. Tumači da su se tako nazivali sami Židovi (i drugi su ih tako nazvali) najprije u Francuskoj nakon građanske emancipacije Židova i poslije Sanhedrina sazvanoga pod Napoleonom, a zatim i u ostaloj Europi, koji su usvojili maksimu proizišlu iz odluka spomenutoga Sanhedrina. Riječ je o zadržavanju izraelitskoga vjerozakona samo u strogo religioznom smislu, a zabacili su ga u nacionalnom smislu. Tako su vjerozakonom ostali izraeliti, a nacionalnošću su mogli postati Francuzi, Nijemci, Hrvati i dr. »Bogoštovne općine takvih poluasimilanata zvale su se — pa i u nas u Hrvatskoj do 1919. — izraelitičke « (Rendić, 1970a, 407). ${ }^{9}$ Upozoravala je na pokušaje uvođenja u hrvatski jezik naziva hebrejski umjesto židovski kao etničke oznake. Zapadni i Europljani iz Srednje Europe, kao i anglofoni u Americi, naziv hebrejski rabili su samo za hebrejski jezik, a Hebreji za ljude biblijskoga Izraela. Židov, tumači Rendić, znači "onaj koji hvali Boga”, a Hebrej znači “čovjek s one obale rijeke” (Rendić, 1970a, 409). Posebnu pozornost posvećuje značenju imena kod Hebreja ističući da je ono značilo bitnost onoga tko ga je nosio, a otkriti svoje ime značilo je »predati sebe duši koja ga je saznala«(Rendić, 1965b). Raspravlja i sa Židovom koji se čudi što je Slavko Goldstein prihvatio njezine argumente o židovskom imenu i vratio to ime u svoj hrvatski tekst (Rendić, 1971a, 345-347). Svojim pisanjem spasila je, vjerujem, uporabu tradicionalnoga židovskoga imena u hrvatskom službenom jeziku.

Molitvu Alenu (Aleinu) naziva najljepšim hebrejskim tekstom, koji se u sinagogalnoj liturgiji i u njezino doba molio tri puta na dan. »Na završetku svakog oficija, ispovijeda posebnost židovskog naroda među narodima, ali stavlja tu posebnost u službu ostvarivanja konačnog jedinstva svih ljudi u priznanju Božjega Jedinstva ('i u onaj dan Vječni će biti Jedan i Jedan će biti Ime Vječnoga')« (Rendić, 1970a, 409-410). Spominje da su i zbog te molitve Alenu križari "masakrirali" Židove po Europi. Pisala je o židovstvu u općem katekizmu, o proslavi njihovih blagdana, poput Hanuke i Jom Kipura (Rendić, 1990a; Rendić, 1991).

8 Francuzi ga prevode Juif, Nijemci Jude, Englezi i Amerikanci Jew.

9 Rendić piše da je zagrebačka izraelitička bogoštovna općina najstarija i najuglednija u Hrvatskoj i najbolja izraelitička općina od Beča do Atene. »Malo je poznato da je ta općina uspjela, sve uz strahoviti gubitak od 80 posto članstva, organizirana i djelotvorna preživjeti II svjetski rat — što je slučaj jedinstven u Jugoslaviji i gotovo jedinstven u Europi pod nacističkim progonstvom.« Poznavala je koliko Židova ima po republikama u Jugoslaviji te je o tom pisala (Rendić, 1971a). 
Osobito kritizira klerike, pa i one učenije među njima, što ne poznaju ili slabo poznaju Talmud, hebrejski jezik Mišne i aramejski jezik Gemare. Upozoravala je da se Židov ne piše malim slovom jer se kod Židova nacija i vjera preklapaju. Osobito ju je ljutilo nepoznavanje judaizma od samih Židova, nazivajući to jednom od najvećih tragedija toga naroda.

Kritizirala je katolički govor o farizejima kao licemjerima i religioznim sadistima, u skladu s evanđeoskim prijekorima protiv njih. Pisala je o drugom tipu farizeja u Novom zavjetu o kojem se u katolicizmu gotovo nikad ne govori, o »egziličkom farizeizmu «. ${ }^{10}$ Razlikuje u židovstvu hasidizam (»hereza u judaizmu«) od ortodoksne mitnagdimske struje. ${ }^{11}$ Mitnagdimi bi bili farizeji u egziličkom judaizmu koji čuvaju poštovanje prema razumu — poput posljednjih tomista u kršćanstvu. Za upoznavanje postbiblijskoga i egziličkoga judaizma utrošila je mnogo truda i sredstava u kupovinu knjiga, ali žalosno ustvrđuje da od toga nema koristi jer o tom nije imala gdje pisati. ${ }^{12}$

Za Mali koncil, ali i za Glas Koncila Rendić je prevodila midraše s francuskoga jezika, a bilješke uz pojedine prevedene tekstove sastavila je po raznim židovskim piscima iz literature koju je imala (Rendić, 1980). Nije dopuštala da se religiozne vrijednosti tih midraša tumače kao utjecaj kršćanstva na židovstvo jer je to smatrala neistinitim. Ističe da je judaizam »posebna, zaokružena, u sebi cjelovita religija, koja se nakon protoshizme razvijala svojim vlastitim putovima, neovisno o kršćanstvu i dapače svjesno ignorirajući kršćanstvo «. ${ }^{13}$ Zaključuje da, ako su Židovi za kršćane problem, kršćani za Židove to nisu. Smatrala je da kršćani zaista moraju poznavati židovstvo i radi toga da o njemu ne bi neuko govorili i sudili mu iz te neukosti (Rendić, 1990b). Za to je smatrala važnim poznavati Sveto pismo.

\section{Kršćanski nauk o Svetom pismu ili judaiziranje kršćanstva?}

Ispravna prožetost Staroga i Novoga zavjeta za Crkvu je i danas konstitutivna. Međutim, već u 2. stoljeću, kada su kršćani proizišli iz židovstva, u Crkvi su postali gotovo zanemariva manjina u odnosu na kršćane obraćene iz poganstva.

10 Rendić u pismu tumači kako je u egziličkom judaizmu farizej u vjerozakonskom pogledu sve, i učitelj i sudac i Zakon i proroci. Sve su druge sljedbe u Izraelu nakon propasti Drugoga Hrama nestale, samo su se farizeji održali. Usp. Osobni arhiv Silvane Burilović Crnov. Faksimilne kopije korespondencije Smiljane Rendić. Pismo Smiljane Rendić Tomislavu Šagi-Buniću od 9. travnja 1979. godine, str. 2.

11 Mitnagdim (mn.) od mitnaged, onaj koji se protivi. Rendić tumači kako je naziv mitnagdim nastao u Litvi (oblikovane tradicijom škole R. Elije, Gaona iz Vilne) upravo u protivljenju spram hasida. Među haside ubraja Martina Bubera i R. Abrahama Joshuu Heschela, a najvećim suvremenim židovskim misliocem smatra Emmanuela Levinasa, nazvavši ga mitnagdom najčistije tradicije. Usp. Osobni arhiv Silvane Burilović Crnov. Faksimilne kopije korespondencije Smiljane Rendić. Pismo Smiljane Rendić Josipu Turčinoviću od 6. rujna 1972. godine, str. 7-8. Spomenimo da je hasidizam dio normativnoga rabinskoga judaizma.

12 Osobni arhiv Silvane Burilović Crnov. Faksimilne kopije korespondencije Smiljane Rendić. Pismo Smiljane Rendić Tomislavu Šagi-Buniću od 9. travnja 1979. godine, str. 5.

13 Osobni arhiv Silvane Burilović Crnov. Faksimilne kopije korespondencije Smiljane Rendić. Pismo Smiljane Rendić Luki Depolu od 17. travnja 1980. godine, str. 1. 
Počela je slabiti svijest o tom da su korijeni Crkve u židovstvu i da je Novi zavjet neshvatljiv bez Staroga, kao što vrijedi i obratno.

U časopisu Kolo Rendić raspravlja s hrvatskim filozofom i teologom Tomom Verešom (1930.-2002.) o historiografskom i egzistencijalnom shvaćanju bogova, ali i o misteriju Krista, podcrtavajući važnost onoga što je već o tom napisano u hebrejskoj Bibliji. Rendić piše o Bogu Izraelovu i Bogu Abrahamovu, o Bogu koji za sebe kaže: "Ja sam onaj koji jesam” i Bogu koji sklapa savez s čovjekom. To je Bog koji je čovjekov saveznik, zaštitnik i pomoćnik te u tom svjetlu govori o Božjoj providnosti, pojmu koji je za nju neodvojiv od biblijskoga poimanja Boga. U tom surječju upozorava na jednu od prvih hereza u Izraelu: saducejsku, koja je nijekala providnost. »Kršćanska Crkva, i u jedinstvu prvih stoljeća i u rascjepima kasnijih, uvijek je čvrsto držala i naučavala tu vjeru u providnost Božju, vjeru da Bog stoji s čovjekom, da se zavjetovao samim Sobom na vječnu pomoć čovjeku, po Svojoj milosti i po zasluzi vjerozakonskih djela čovjekovih, to jest po hodu čovjekovu u Njegovoj Prisutnosti« (Rendić, 1970b, 821). U kršćanstvu se ta vjera u Božju providnost izrazila prvotno u Kristovu posredništvu između Boga i čovjeka, poslije u katolicizmu i pravoslavlju u Marijinu i svetačkom posredništvu između Krista i čovjeka. Ističe da je to uvijek ista vjera u providnost Jednoga. Naglašava da u molitvi Očenaša, koju nas je Krist naučio, nema ni jedne misli koje već ne bi bilo u hebrejskoj Bibliji i u tradiciji judaizma te da se najveći dio javne molitve Katoličke crkve sastoji od psalama hebrejske Biblije, odnosno Staroga zavjeta (Rendić, 1970b, 822). Rendić, također, kritizira naglašavanje misteričnoga Krista (misterij utjelovljenoga, umrloga i uskrsloga Boga), a zanemarivanje povijesnoga Isusa, koji je bio Židov i koji je učio ljude moliti Boga Oca, koji je poticao na molitvu i upozoravao ljude što je dobro, a što zlo činiti. Nezgrapno koristi za Isusa riječ moralizirao umjesto upozoravao, što joj je Vereš u raspravi spočitnuo (Vereš, 1970, 828). Rendić ističe Isusovo citiranje Staroga zavjeta (Pnz 6,5 i Lev 19,18) dok govori o dvjema zapovijedima ljubavi. Naglašava Božje predstavljanje kao "Ja sam onaj koji jest", koje se nalazi iza zapovijedi o ljubavi prema bližnjemu te ju naziva "teškom Božjom opomenom”. Objašnjava da su talmudisti tumačili da je onaj koji pozdravi bližnjega prije nego je blagoslovio Boga ravan idolopokloniku. »Mi smo tu: Bog je postao 'bližnji', Bog je sveden na 'bližnjega', oblikuje se idolatrija bližnjega. U misli 'nove teologije', Bog je prestao biti Radikalno Drugi. Bog je prestao biti Ja koji je čovjeku govorio ti i prije pojave Isusa Krista u Galileji. Bog je prestao biti Otac kojemu je i Isus govorio Oče « (Rendić, 1970b, 825). Rendić smatra da je ostala nerazjašnjena Verešova rečenica: »Sada čovjek ostaje suočen jedino s Bogom kojega naviješta kršćansko Evanđelje, tj. s Bogom koji je postao čovjekom, umro i uskrsnuo od mrtvih te se najjasnije otkriva u nesebičnoj, djelotvornoj ljubavi čovjeka prema čovjeku« (Vereš, 1969, 219). Stoga, ulazi u raspravu s "novom teologijom", s njezinim tumačenjem soteriologije i oštro zaključuje da je Bog prestao biti Bog Abrahamov i da je Božja objava svedena na Evanđelje, a Evanđelje na idolatriju bližnjega (Rendić, 1970c, 1188).

Vereš je njezino pisanje nazvao »judaiziranje kršćanstva«, pisanje sa »svojevrsnih, u nas neobičnih i neuobičajenih talmudsko-kršćanskih pozicija « (Vereš, 
1970, 826). Kritizira činjenicu da su za Rendić Stari zavjet i Talmud vrhovni i najmjerodavniji tumači kršćanstva te da je Krist dva puta prikazan samo kao »citatolog Staroga zavjeta i kao moralizator-legalist u starozavjetnom smislu. Ono 'novo' što je Krist donio na svijet ne izlazi na vidjelo, utapa se u 'staro' « (Vereš, 1970, 826). Odnosno, još oštrije ističe da je ona njegov članak uzela za polazište svoje antimodernističke kampanje protiv suvremenih katoličkih neoteologista i neofita da bi završio vizijom zloglasne marcionske hereze kao bitne odrednice svekolikoga zbivanja u onodobnom kršćanstvu i u suvremenom svijetu uopće. Rendić njegove kritike smatra samo još jednim dokazom znatno raširene pojave u onodobnoj Crkvi, koju je nazvala »Marcionova pobjeda«.

Riječ je o crkvenom “odbacivanju tereta Staroga zavjeta”. ${ }^{14}$ „Čini se da je u Crkvi konačno nastala kriza radikalnog odbacivanja hebrejskog elementa: Ecclesia gentium kao da se konačno, u nekoj neurotičnoj freneziji, otkida od svoga korijena — zaboravljajući da je taj korijen samo kalem na svetu maslinu Izraela, i da nakalamljena grana živi od stabla: 'Ne nosiš ti korijen, nego korijen nosi tebe' - to je iz Novoga zavjeta, iz Pavla Apostola (Rom. 11,18). Isus je Židov, oče Tomo, Centralni Židov uvijek, a nije 'Verbum bez subjekta i objekta', kako bi ga htjele prikazati neke 'dejudaizantske' struje u Crkvi« (Rendić, 1970c, 1189). Rendić u biti upozorava da se ne smije dijeliti Novi od Staroga zavjeta te za sebe kaže da je cijeli svoj duhovni i intelektualni život sagradila na definiciji švicarskoga pastora, teologa i hebraista Wilhema Vischera (1895.-1988.) da Stari zavjet govori što je Isus Krist, a Novi zavjet govori tko je Isus Krist. Pozivajući se na belgijskoga književnoga kritičara Paula Demanna (1919.-1983.) žalosno ustvrđuje da cijela »Crkva dubinski trpi od posljedica prve i najteže šizme: šizme između sebe i Izraela «. ${ }^{15}$

Joseph Ratzinger govori o raširenoj kušnji da se Novi zavjet tumači na čisto duhovan način, da ga se odvoji od svake socijalne i političke važnosti. Nasuprot tomu, političke teologije zagovaraju teologizaciju jednoga pojedinačnoga političkoga puta, koji proturječi novosti i širini Isusove poruke. Unatoč tomu, bilo bi pogrješno takve tendencije nazivati judaizacijom kršćanstva, jer Izrael svoju poslušnost prema konkretnim socijalnim uredbama Tore povezuje sa zajedništvom podrijetla "vječnoga Izraela" i ne proglašava ju sveopćim političkim receptom. Ratzinger smatra da će kršćanstvo, u cjelini gledajući, »dobro učiniti ako s poštovanjem bude gledalo na ovu Izraelovu poslušnost jer će tako bolje uočavati velike imperative Dekaloga, koje kršćanstvo mora prenositi u prostor sveopće Božje obitelji koju nam je darovao Isus kao ‘novi Mojsije'. U njemu vidimo ispu-

14 Od samih početaka dvije su suprotnosti ugrožavale Crkvu: s jedne strane, pogrješan legalizam protiv kojega se je borio Pavao i koji je, nažalost, u čitavoj povijesti označavan nesretnim nazivom judaizam te s druge strane, odbacivanje Mojsija i Proroka (Staroga zavjeta) koje je najprije izrazio Marcion u 2. stoljeću. To je velika kušnja novoga vijeka. Stoga, nije slučajno da je Harnack kao vodeći teolog liberalne teologije zahtijevao da prihvatimo Marcionovo nasljeđe i kršćanstvo »oslobodimo tereta Staroga zavjeta« (Ratzinger, 2007, 135).

15 Osobni arhiv Silvane Burilović Crnov. Faksimilne kopije korespondencije Smiljane Rendić. Pismo Smiljane Rendić Tomislavu Šagi-Buniću od 28. ožujka 1967. godine, str. 7. 
njeno obećanje dano Mojsiju: 'Proroka kao što sam ja, iz tvoje sredine, od tvoje braće, podignut će ti Gospodin, Bog tvoj' (Pnz 18,15)« (Ratzinger, 2007, 135). Sve većemu gubljenju svijesti Crkve o zajedničkom duhovnom nasljeđu sa Židovima pridonosio je nepomirljiv stav Židova prema kršćanskomu priznanju Isusa Mesijom i njihovu pozivanju na židovsku Bibliju. S druge strane, na putu njihovu međureligijskom dijalogu stajala je i kršćanska optužba Židova za bogoubojstvo i kolektivnu odgovornost za Isusovu smrt.

\section{O uzrocima kršćanskoga antisemitizma i o neodrživosti teze o kolektivnoj odgovornosti Židova za bogoubojstvo}

Smiljana Rendić još je za vrijeme trajanja Koncila, i prije nego je izglasana deklaracija Nostra aetate, pisala o prijedlogu kardinala Augustina Bee (1881.1968.), koji je podnio koncilskim ocima uime Sekretarijata za sjedinjenje kršćana, da Koncil i formalno skine sa židovskoga naroda vjekovnu optužbu zbog bogoubojstva (Rendić, 1964a, Rendić, 1968). Istaknula je da je taj prijedlog pripremljen blagoslovom Pija XII. i ohrabrenjem Ivana XXIII., a nadahnut čovjekom koji je dvadeset zadnjih godina svojega života posvetio proučavanju uzroka antisemitizma i nastojanju da ga se iskorijeni. Riječ je o židovskom povjesničaru iz Francuske Julesu Isaacu (1877.-1963.), koji je u svojim člancima i knjigama pisao o uzrocima antisemitizma i o neodrživosti teze o kolektivnoj odgovornosti Židova za bogoubojstvo.

Rendić je opširno pisala o Isaacovim susretima s papama Pijom XII. i Ivanom XXIII., o međunarodnim konferencijama te općenito o njegovoj misli i djelu, što je na neki način nadahnulo deklaraciju Nostra aetate. ${ }^{16}$ Naime, Isaacovi susreti s papama rezultirali su time da je papa Ivan XXIII. dao izbrisati iz liturgije Velikoga petka riječi perfidis ("nevjerni") i perfidiam ("nevjera"), koje su se odnosile na Židove, odnosno označavale su židovsku nevjeru u Isusa Krista (Rendić, 1993). ${ }^{17}$ Rendić je u više navrata pisala o tom kako su Židovi izrazito cijenili papu Ivana XXIII., koji ih je osobito ganuo kad je 1960. primivši delegaciju američke židovske organizacije United Jewish Appeal sišao s podija, pristupio tim ljudima i toplo im rekao: »Ja sam Josip, vaš brat « (Post 45,4). Te Papine riječi teolozi religija nazivaju povijesnima.

Glavne zasade Isaacova programa Rendić sažima sljedećim riječima: »Treba naglasiti da je Krist bio Židov, da je historijski neodrživo tumačiti židovsku rasutost po svijetu kao kaznu za bogoubojstvo, da između Staroga i Novoga Zavjeta

16 Teolog religija Nikola Bižaca $(1998,401)$ također ističe da je susret pape Ivana XXIII. s Julesom Isaacom 13. lipnja 1960. »bio uistinu providonosno važan za daljnju artikulaciju Papine odluke koja je potom u konačnici dovela do deklaracije NA «.

17 Bižaca piše da je Ivan XXIII. već 27. ožujka 1959., na prvi Veliki petak svojega pontifikata dao da se iz Sveopće molitve izbace za Židove uvrjedljive riječi Oremus et pro perfidis Judaeis, te da je te iste godine, 15. listopada, odredio da se iz molitve posvete čovječanstva Kristu Kralju odstrane izrazi koji bi mogli vrijeđati Židove i muslimane. Dakle, ne nakon susreta s Isaacom kako Rendić piše (Bižaca, 1998, 401). 
postoji izravna uzročna veza koja čini neosnovanim prezir kršćanske pučke tradicije prema židovstvu« (Rendić, 1964a). Isus je cijeli svoj zemaljski život obdržavao propise Zakona koji je Bog dao narodu Hebreja u Starom zavjetu. Na tim je tezama i Rendić gradila svoju misao o judaizmu i Židovima te o odnosu kršćana prema Židovima.

Tako Rendić podsjeća na Isusove riječi učenicima da nije došao dokinuti Zakon, nego dopuniti (Mt 5,17-19) te na Isusove riječi Samarijanki da »spasenje dolazi od Židova « (Iv 4,22). Tim je riječima, ističe Rendić, Isus izrazio povijesni i moralni smisao svojega naroda, koji je prije Isusova dolaska jedini vjerovao u Njegova Oca - Boga Abrahamova, naroda koji je jedini čuvao obećanje o njegovu dolasku. Iz toga zaključuje da kršćani, koji svoju vjeru zasnivaju na Kristu, ne smiju prezirati narod iz kojega je Krist izišao i čijim je jezikom govorio, narod koji ga je »jedini svjesno čekao tisuće godina, ako Ga i nije prepoznao kad je došao. Većina Ga nije prepoznala, manjina Ga je raspela, ali odgovornost cijeloga naroda za Raspeće stvarno ne može biti kolektivna « (Rendić, 1964a). Naglašava da za svojevrsnu kletvu »krv Njegova na nas i na djecu našu « mogu biti odgovorni samo oni koji su ju izrekli. Smatra da Isaac ispravno tumači da tradicionalno pučko mišljenje o dijaspori kao dokazu o kolektivnom ostvarenju toga samoprokletstva ne može biti točno jer je dijaspora započela daleko prije Isusova rođenja te je u Isusovo vrijeme Židova bilo posvuda po Mediteranu. O tom Rendić govori već 1963. godine ističući da je protukršćanstvo nastalo po modelu antisemitizma, koje je postojalo u Rimskom Carstvu još prije Krista (Rendić, 1963).

Rendić piše da optužba za bogoubojstvo nikada nije bila izričito formulirana u katoličkoj teologiji, ali je na području kršćanske civilizacije trajala praktički stoljećima i stvarala ili pojačavala antisemitsku psihozu masa, pa su joj se tragovi osjećali čak i u katoličkoj katehezi i katoličkoj liturgiji (Rendić, 1964a). U prilog Isaacovoj neprihvatljivosti teze o kolektivnoj odgovornosti Židova za Isusovu smrt Rendić iznosi i moralni razlog da je Abraham, praotac Židova, prvi u povijesti formulirao individualnost krivnje i individualnost zasluge: »Daleko od Tebe da kazniš pravednika s grešnikom « (Post 18,25). Naglašava važnost što će u liturgiji uskrsne noći zauvijek ostati riječi vjere u jedinstvo Staroga i Novoga zavjeta u Kristu, riječi u kojima je Izrael, narod Božji, simbol djece Božje svih rasa i jezika, a Abraham, praotac Hebreja, otac svih vjernih: »Daj da u djecu Abrahamovu i u izraelsko dostojanstvo prijeđe punina cijeloga svijeta « (Rendić, 1964a).

Rendić često koristi izraz antisemitizam, koji označava neprijateljstvo prema Židovima na religijskoj, nacionalnoj ili rasnoj osnovi. Tako ističe da je svakomu antisemitizmu korijen u teološkom i da je upravo zato što je crkveno učiteljstvo to shvatilo došlo do promjene i u liturgijskim tekstovima. ${ }^{18}$ Međutim, nameće se pitanje je li Crkva o antisemitizmu prekasno progovorila?

18 Osobni arhiv Silvane Burilović Crnov. Faksimilne kopije korespondencije Smiljane Rendić. Pismo Smiljane Rendić Vladimiru Pavliniću od 30. siječnja 1968. godine, str. 12. 


\section{Je li Crkva o antisemitizmu prekasno progovorila?}

Smiljana Rendić u vrijeme Koncila, ali i nakon njega, pisala je o holokaustu i aktivnostima crkvene hijerarhije, pa i Svete Stolice oko sprječavanja pogibije Židova u nacističkim krematorijima. U tekstovima koje je objavila u Glasu Koncila 1964. i 1965. stala je u obranu ugleda pape Pija XII. (Rendić, 1964b; Rendić, 1965c), a u pismima nekoliko godina poslije piše o političkom moralu crkvenih poglavara i šutnji “iz opreza”. ${ }^{19}$ Iz njezina pisanja uočavamo postojanje dviju struja koje različito promatraju pontifikat pape Pia XII. Jedna struja smatra da je samo javna osuda holokausta mogla spriječiti smrt milijuna ljudi, a druga struja smatra da se protiv pape Pia XII. vodila strašna nepravedna promidžba i da je učinio sve što je mogao (Blet, 2004). Konačni sud o njegovu djelovanju tijekom Drugoga svjetskoga rata moći ćemo dati tek kada se konzultira cijela dokumentacija koja se čuva u vatikanskim arhivima. Prema propisima ona se ne smije konzultirati prije nego prođe sedamdeset godina od papine smrti. Međutim, odlukom pape Franje 2. ožujka 2020. deklasificirani su arhivi pape Pija XII., osam godina prije isteka roka. Papa Franjo djelovanje Crkve tijekom Drugoga svjetskoga rata smatra pozitivnim te sve ono što je papa Pio XII. činio smatra uvjerljivim temeljeći svoj sud na konzultiranim dokumentima. ${ }^{20}$ Papa za cilj uzima istinu i govori da je se ne treba bojati (Franjo i Skorka, 2013, 140-141).

Rendić je kritizirala tekstove koji su i nakon Koncila odisali antisemitizmom. Upozoravala je na pojedine elemente koji su u popularnom katoličkom tisku u Hrvatskoj za vrijeme Drugoga svjetskoga rata možda odavali dojam solidariziranosti s nacističkim režimom. Bila je ponosna na skupinu kojoj je pripadala (Rendić, 1990c), a koja se je okupljala oko isusovca Stjepana Poglajena (1906.-1990.), za koga kaže da je prvi koji je »u hrvatskom katolicizmu počeo sustavnu javnu borbu protiv nacizma «.21 Važno je, također, poznavanje dokumenata koji se na-

19 Osobni arhiv Silvane Burilović Crnov. Faksimilne kopije korespondencije Smiljane Rendić. Pisma Smiljane Rendić Vladimiru Pavliniću od 28. lipnja 1967 i 30. siječnja 1968. godine.

20 Cjelokupni vatikanski arhiv iz toga razdoblja ima oko dva milijuna dokumenata ili 323 dužna metra arhivskoga gradiva u kutijama, fasciklima, registratorima i sl. Gradivo pokriva široko područje djelovanja: radnje Svete Stolice tijekom Drugoga svjetskoga rata, njezinu diplomaciju, sporazume, humanitarni rad Crkve, izvještaje o određenim vjerskim i političkim pitanjima, obrazovna izvješća i dokumente koji se odnose na Svetu Stolicu (IKA, 2020).

21 Osobni arhiv Silvane Burilović Crnov. Faksimilne kopije korespondencije Smiljane Rendić. Pismo Smiljane Rendić Josipu Turčinoviću od 6. rujna 1972. godine, str. 6. Tu treba spomenuti vrlo utemeljenu teologijsku kritiku nacizma iz pera A. Živkovića, što je objavljeno u Bogoslovskoj smotri nekoliko godina prije Drugoga svjetskoga rata, premda se ona prvenstveno odnosila na upozorenje nazočnosti poganskih i nekršćanskih elemenata u djelu Alfreda Rosenberga Der Mythus des XX. Jahrhunderts. Drugi je važan tekst H. Boškovića čitan nekoliko godina kasnije na Hrvatskim socijalnim tjednima u Zagrebu, u kojem se u filozofskom ključu upućuje na idolatrijske sadržaje u shvaćanju države kod W. G. Hegela. Ipak, s puno većim odjecima i kritičkom oštrinom, Poglajen je u isusovačkom časopisu Život izvještavao o progonima katolika u Njemačkoj i nemilosrdno raščlanjivao totalitarizam te zlokobne ideologije, stavljajući ju u isti red i rod s komunizmom (Jukić, 1997, 451). 
laze u jeruzalemskim arhivima, a govore o zauzimanju kardinala Alojzija Stepinca za progonjene Židove u Drugom svjetskom ratu. ${ }^{22}$

U pismima je, također, znala reći da je Crkva o Židovima i antisemitizmu prekasno progovorila te da je i to što je rekla na Koncilu bilo premalo. ${ }^{23}$ Međutim, kada se poznaje cijeli tijek nastajanja Nostra aetate, složit ćemo se s Nikolom Bižacom da je pravo čudo da je do toga koncilskoga dokumenta uopće došlo ${ }^{24}$ te da je dao veliki prinos početku razdoblja prijateljstva i uzajamnoga razumijevanja u dijalogu između katolika i Židova. Dokument je dao, kako papa Franjo reče, »konačno 'da' židovskim korijenima kršćanstva i neopozivo 'ne' antisemitizmu « (IKA, 2015). ${ }^{25}$

\section{Zaključak}

Katolička novinarka Smiljana Rendić pišući o židovstvu polazila je od temeljne činjenice da je Isus Krist bio Židov. Rodio se je, odrastao i proživio cijeli svoj zemaljski život pod Zakonom koji je Bog dao narodu Hebreja u Starom zavjetu. Do smrti je obdržavao propise toga Zakona i izričito je rekao da ga nije došao dokinuti, nego dopuniti, to jest usavršiti. Stoga joj nikako nije bilo jasno da netko od kršćana može mrziti Židove, pa ako ih i smatra odgovornima za Isusovu smrt, što je svakako držala neprihvatljivim. Smatrala je židovski narod jedinstvenim po tom što je jedini dao Boga, proroke, apostole, Mariju, prvu Crkvu, Bibliju.

Na tragu deklaracije Nostra aetate podsjeća na veliko zajedničko duhovno nasljeđe Staroga zavjeta. Navodi da se za Kristovu smrt ne mogu optužiti ni svi ondašnji Židovi bez razlike, ni današnji Židovi. Krist je dragovoljno pretrpio muku i smrt iz ljubavi, zbog grijeha svih ljudi, da bi svi postignuli spasenje. Odbacuje predodžbu da su Židovi odbačeni, prokleti i nevjerni te smatra neodrživom tvrdnju da je njihova rasutost po svijetu kazna za bogoubojstvo. Podcrtava da između Staroga i Novoga zavjeta postoji izravna uzročna veza. Osuđuje svaki oblik antisemitizma i ističe potrebu zajedničkoga prevladavanja tragičnih posljedica

22 Toj tematici vrijedan doprinos dala je Esther Gitman, koja je napravila istraživanje o spašavanju Židova u NDH te ističe kako je Stepinac dizao svoj glas protiv brutalnosti nacista i ustaša (Gitman, 2012, 155-191).

23 Osobni arhiv Silvane Burilović Crnov. Faksimilne kopije korespondencije Smiljane Rendić. Pismo Smiljane Rendić Vladimiru Pavliniću od 30. siječnja 1968. godine, str. 12.

24 U pripravnoj se fazi Koncila nije dalo naslutiti mogućnost da se on u službenom obliku pozabavi problemom nekršćanskih religija. Potom, bilo je nekoliko revizija teksta. Dogodila se je "listopadska kriza", potom i Sveti rat arapske vlade protiv toga — po njihovu mišljenju — kapitulantskoga i izričito prozelitskoga dokumenta. Bižaca kaže da je cijeli Bliski istok planuo uznemirenošću zbog toga dokumenta, koji je »oslobađao židovski narod od optužbe za bogoubojstvo te je time dokidao bilo kakvo teološko opravdanje tradicionalnog antižidovstva u redovima kršćana« (Bižaca, 1998, 411). Šagi-Bunić kaže da su se u arapskim zemljama bojali »političkih posljedica u prilog židovske države u Palestini, koju arapske zemlje ne priznaju i s kojom imaju svoje račune. Koncil, međutim, nema kod toga političke pozadine ni političkih ciljeva, već samo hoće reći istinu o pravom odnosu između kršćanstva i ljudi koji ispovijedaju židovsku vjeru te krvno potječu od Abrahama kao pripadnici starozavjetnog izabranog naroda « (Šagi-Bunić, 1986, 266-267.)

25 Papa Franjo više je puta naglasio da kršćani i Židovi nisu više stranci nego prijatelji i braća (Radio Vatikan, 2015). 
holokausta. Iako je pisala o zauzetosti Crkve oko sprječavanja pogibije Židova, znala je u nekim trenutcima kritizirati Crkvu da je o Židovima i antisemitizmu premalo i prekasno progovorila. Poznavala je dobro židovsku povijest i tradiciju, jezik i kulturu. Svojim pisanjem spasila je, vjerujem, uporabu tradicionalnoga židovskoga imena u hrvatskom službenom jeziku.

Upućivala je na međusobno poznavanje i poštivanje jednih i drugih, koje se osobito stječe učenjem i poznavanjem temeljnih židovskih i kršćanskih tekstova. Smetalo ju je poistovjećivanje farizeja s licemjerima. Poput židovskoga rabina Jacoba Neusnera, koji je s poštovanjem ušao u dijalog s Isusom, Smiljana Rendić s poštovanjem je ulazila u dijalog s Torom i Talmudom, nastojeći protumačiti zašto Židovi vjeruju u Mojsijevu Toru i ovdje na Zemlji stvaraju vidljivo Božje kraljevstvo svećenika i svetoga naroda, a kršćani vjeruju u Isusa Krista i Radosnu vijest o njegovoj vladavini u Kraljevstvu nebeskom. Židovi smatraju neshvatljivom predodžbu o Bogu koji je na jedinstven način utjelovljen u jednom čovjeku, kršćanima je nerazumljiv pojam izabranoga Božjega naroda Izraela. Kršćani vjeruju da je Isus Krist Riječ Božja koja je postala tijelo u svijetu, a za Židove je Riječ Božja nazočna ponajviše u Tori. Nijedna strana ne može zamisliti analogiju, u razumljivim okvirima, s onim što je najsvetije drugoj. Stoga u raspravi i dijalogu treba poći od srži stvari koja je zajednička, od obiju strana prihvaćene istine: Tore. Obje vjerske tradicije imaju u temelju Jedinoga Boga, Boga Saveza, koji se ljudima objavljuje po svojoj Riječi.

Rendić je u Tori nalazila uporište i za samu raspravu kojoj je bila sklona. Ono što za nju nije ulazilo u raspravu tvrdnja je da kršćanin ne može biti antisemit. Ili si kršćanin ili antisemit. Kad u dijalogu shvatimo da ne možemo dijeliti vjeru svojega sugovornika, to nije razlog da ga odbacimo, nego da imamo razumijevanja za njegove razloge, svjesni da nam je čovjek uvijek veći i važniji od tih razloga na koje se poziva, kao što je i Isus veći od onoga što je izrekao i što je o njemu napisano, a što mi kršćani prihvaćamo darom vjere. Silno joj je bilo stalo do kršćansko-židovskoga dijaloga te je bila prijateljski povezana sa židovskom zajednicom u Rijeci.

Katolička novinarka Smiljana Rendić zasigurno može poslužiti kao svijetli primjer svim novinarima. Njezini tekstovi koje smo analizirali u ovom članku pokazuju da je ono što je pisala prije pola stoljeća aktualno i danas kad se suočavamo s jačanjem antisemitizma u Europi. Njezini tekstovi mogu pomoći kršćanima da postanu bolji kršćani, a Židovima da postanu bolji Židovi. Pisala je kako bi pomogla i kršćanima i Židovima u autentičnom življenju njihove vjere, miroljubivom dijalogu i mirnom suživotu.

\section{Literatura}

Bižaca, Nikola (1998). Kako je nastajala saborska deklaracija Nostra aetate o odnosima Crkve prema nekršćanskim religijama. Bogoslovska smotra, 70(3), 399-434.

Blet, Pierre (2004). Pio XII. i Drugi svjetski rat prema vatikanskim arhivima. Zagreb: Kršćanska sadašnjost. 
Burilović Crnov, Silvana (2019). Smiljana Rendić: Katolička novinarka i pratiteljica Drugoga vatikanskog sabora (Doktorski rad). Sveučilište u Splitu.

Čutura, Vlado (2012). Smilje zlatnog pera. U: Smiljana Rendić, Katolički identitet i hrvatski preporod (str. 7-40). Zagreb: Glas Koncila.

FRA (2018). European Union Agency for Fundamental Rights, Experiences and perceptions of antisemitism Second survey on discriminationand hate crime againstJews in the $E U$. Luxembourg: Publications Office of the European Union. URL: https://fra.europa.eu/sites/default/files/fra_uploads/fra-2018-experiences-and-perceptions-ofantisemitism-survey_en.pdf $(\overline{0} 6.12 .2021$.

Franjo; Skorka, Abraham (2013). O nebu i o zemlji: Razmišljanja pape Franje o obitelji, vjeri i ulozi Crkve u 21. stoljeću. Zagreb: VBZ.

Gitman, Esther (2012). Kad hrabrost prevlada: Spašavanje i preživljavanje Židova u Nezavisnoj Državi Hrvatskoj 1941.-1945. Zagreb: Kršćanska sadašnjost.

IKA (2015). Otvoreni vatikanski arhivi pape Pija XII. Informativna katolička agencija (1. srpnja). URL: https://ika.hkm.hr/novosti/papa-o-vaznosti-dijaloga-krscana-i-zido$\mathrm{va} /(06.12 .2021$.

IKA (2020). Otvoreni vatikanski arhivi pape Pija XII. Informativna katolička agencija (2. ožujka). URL: https://ika.hkm.hr/novosti/otvoreni-vatikanski-arhivi-pape-pija-xii/ (06.12.2021.)

Jukić, Jakov (1997). Lica i maske svetoga. Zagreb: Kršćanska sadašnjost.

Neusner, Jacob (2010). Rabin razgovara s Isusom. Zagreb: Kršćanska sadašnjost.

Radio Vatikan (2015). Papa Franjo: Židovi i kršćani su prijatelji i braća. Bitno.net (1. srpnja). URL: https://www.bitno.net/vijesti/vatikan/papa-franjo-zidovi-i-krscanisu-prijatelji-i-braca/ (06.12.2021.)

Ratzinger, Joseph (2007). Isus iz Nazareta. Split: Verbum.

Rendić, Smiljana (1963). Ti si Petar: Znat ćeš kad budeš dostojan. Glasnik sv. Antuna Padovanskoga, 2(11), 4. [Potpisano: Vjera Marini.]

Rendić, Smiljana (1964a). U tebi će biti blagoslovljeni svi narodi. Glas Koncila, 3(11), 7. lipnja, 3. [Potpisano: Berith.]

Rendić, Smiljana (1964b). Zašto nisi progovorio? Glas Koncila, 3(8), 8.-26. travnja, 10. [Potpisano: Berith.]

Rendić, Smiljana (1965a). Bog i bogovi. Marija, 3(4), 163-167. [Potpisano: Vjera Marini.]

Rendić, Smiljana (1965b). Tko si ti, Gospodine? Marija, 3(2), 68-69. [Potpisano: Vjera Marini.]

Rendić, Smiljana (1965c). Zabranjena predstava. Glas Koncila, 28. ožujka, 4. [Potpisano: SR.]

Rendić, Smiljana (1968). Umro "Kardinal ekumenizma". Glas Koncila, 7(24), 1. prosinca, 3. [Potpisano: TT.]

Rendić, Smiljana (1970a). O imenu Židova. Kritika, 3(12), 406-410.

Rendić, Smiljana (1970b). Bog, to su drugi. Kolo, 128(7), 818-825.

Rendić, Smiljana (1970c). Knut oca Tome. Kolo, 128(10), 1187-1192.

Rendić, Smiljana (1971a). O Hrvatima, svetištima i Židovima. Kritika, 4(17), 343-347.

Rendić, Smiljana (1971b). Kriza Crkve i kriza vjere. Kritika, 4(19), 640-653.

Rendić, Smiljana (1980). Iz hebrejske vjerske baštine. Glas Koncila, 19(9), 4. svibnja, 10. [Potpisano: SR.]

Rendić, Smiljana (1990a). Kardinal Ratzinger: Židovstvo u općem katekizmu. Glas Koncila, 29(44), 4. studenoga, 4.

Rendić, Smiljana (1990b). Kršćanin mora poznavati židovstvo. Glas Koncila, 29(10), 11. ožujka, 5 . 
Rendić, Smiljana (1990c). Patrova sjetva. Glas Koncila, 29(45), 11. studenoga, 9.

Rendić, Smiljana (1991). Hanuka u 12 europskih glavnih gradova. Glas Koncila, 30(1), 6. siječnja, 10. [Potpisano: SR.]

Rendić, Smiljana (1993). Svojim je rukama zagrlio srce svijeta. Glas Koncila, 32(24), 13. lipnja, 4. [Potpisano: SR.]

Rendić, Smiljana (2004). Židovska tradicija o Mesiji. U: Ivan Mužić, Zlodusi u Hrvatskoj (str. 69-70). Split.

Riegert, Bernd (2021). Židovi napuštaju Europu. Deutsche Welle (13. listopada). URL: https:// www.dw.com/hr/\%C5\%BEidovi-napu\%C5\%A1taju-europu/a-59494138 (06.12.2021.)

Šagi-Bunić, Tomislav (1986). Ali drugog puta nema. Zagreb: Kršćanska sadašnjost.

Vereš, Tomo (1969). Kršćanin i suvremena tehnika. Kolo, 127(3), 213-220.

Vereš, Tomo (1970). Judaiziranje kršćanstva. Kolo, 8(7), 826-829.

Arhivsko gradivo

Osobni arhiv Silvane Burilović Crnov. Faksimilne kopije korespondencije Smiljane Rendić.

\section{A Christian Cannot be an Anti-Semite}

A Contribution to Christian-Jewish Dialogue by Catholic Journalist Smiljana Rendić Silvana Burilović Crnov**

\section{Summary}

The first female Croatian Catholic journalist, Smiljana Rendić, has made a substantial contribution to Christian-Jewish dialogue. Still relevant today are the topics she covered during the Second Vatican Council in an effort at clarification for the Church Press, while in the post-conciliar period she focused on the "Nostra aetate" Declaration and the dialogue between Christians and Jews. Today, modern Jews are complaining of a rise in anti-Semitism in Western Europe. The paper presents Rendic's thoughts on the relationship between the Old and New Testaments, on the attitude of Jesus Christ towards the Law, on Judaism and the Jews whom she considered a unique people. It analyzes the causes of Christian anti-Semitism and the unsustainability of the thesis concerning their collective responsibility for deicide. It contextualizes her interpretation of Jewish culture, language, and customs, and questions the viability of the claim that the Church spoke belatedly on anti-Semitism. Rendić often entered into discussions by taking a stance founded in the Torah, which she knew well. She did not discuss the fact that a Christian cannot be anti-Semitic. The author of the article concludes that Rendic endeavoured in her writing to encourage Christians and Jews to live their faith authentically and to strive toward a peaceful coexistence. The author uses the hermeneutic method of reading texts in their context.

Keywords: Smiljana Rendić; Jews; Christian-Jewish dialogue; anti-Semitism; deicide; collective responsibility; Nostra aetate; Judaization of Christianity

* Silvana Burilović Crnov, Ph.D., Head of the Information Department of the Split-Makarska Archdiocese Press Office. Address: Poljana kneza Trpimira 7, 21000 Split, Croatia.

E-mail: silvana.burilovic@gmail.com 